\title{
The Debate on Independence at the Crossroads of the Administrative State, Delegation and IRA s
}

Judicial independence is a cornerstone of the rule of law and, therefore, of democratic states. In private disputes, judges must be and be seen independent in order to deliver impartial decisions. In public law disputes, judicial independence is an element of checks and balances that the cocktail called "democracy" offers: the judiciary is expected to control the excesses of the legislative and executive powers, while the legislative and the executive are expected to control the judiciary. Even more, "insofar as the state employs the judges, public law disputes might be thought to require an even greater degree of judicial distance, or structural capacity for independent evaluation of parties' claims". ${ }^{1}$ These acts of mutual control are deemed necessary for a society in which there is trust in the state and its institutions. Two assumptions underlie this type of democratic system. First, checks and balances are necessary only if one presumes that the three branches of government would have the tendency to exercise their powers excessively or to the detriment of the other branches. If the presumption was that government power can be exercised without excess, checks and balances would not be necessary. Furthermore, power could be exercised in excess of its mandate only by imperfect beings. The source of the checks and balances existing in many democratic systems is, hence, the belief that human beings are imperfect.

Second, democratic systems aim to be trusted, embraced and validated during elections. A lack of trust may result in revolt, revolution, conflict and demise of the system. The citizen's trust grounds democracy and justifies its existence. Therefore, the ultimate beneficiary of the processes constituting the checks and balances should be the citizen.

Trust is achieved by observation, engagement and participation. The citizen most closely engages with the executive and the judiciary, sometimes on a daily basis. The image that the executive and the judiciary project plays a crucial role in maintaining the citizen's trust and in safeguarding democracy.

1 Jackson, Vicki C. "Judicial Independence: Structure, Context, Attitude." Judicial Independence in Transition. Ed. Anja Siebert-Fohr. Heidelberg: Springer, 2012, p. 20. 
Independence is a notion that is intimately associated with the judiciary and the performance of justice. Russell has shown that it was in the "more well-established liberal democracies" that contemporary concerns about judicial independence have been triggered. ${ }^{2}$ Judicial independence is considered "a fundamental instrument in order to establish and implement a system of impartial and fair rules". ${ }^{3}$ Feld and Voigt introduced the distinction between de jure and de facto judicial independence and showed that there is a relation between judicial independence and economic growth and even between judicial accountability and higher income and less corruption. ${ }^{4}$

Classic works on judicial independence highlight the fact that this concept encompasses more than just freedom from blunt interventions by the other branches of the government or from within the hierarchy. In fact, judicial independence imposes system requirements that deal with recruitment patterns, allocation of cases and financial independence. ${ }^{5}$ Such works pay generous attention to domestic law and less attention to international law. Also, these early efforts have led to the adoption of international standards for judicial independence. ${ }^{6}$

If the growth of judicial power and judicial activism has been accompanied by discussions about judicial independence, the growth of the administrative state has been supplemented by a debate about administrative justice.

Zellick has noted that all countries have a court system and most countries have a "parallel system of court-like bodies that adjudicate on a range

2 Russell, Peter H. "Judicial Independence in Comparative Perspective." Judicial Independence in the Age of Democracy: Critical Perspectives from Around the World. Eds. Peter H. Russell and David M. O'Brien. Charlottesville: University of Virginia Press, 2001, p. 301.

3 Guarnieri, Carlo, and Daniela Piana. "Judicial Independence and the Rule of Law: Exploring the European Experience." The Culture of Judicial Independence: New Conceptual Dimensions and Conceptual. Eds. Shimon Shetreet and Christopher Forsyth. Leiden: Brill, 2011.

4 Feld, Lars, and Stefan Voigt. "Economic Growth and Judicial Independence." European Journal of Political Economy 19.3 (2003): pp. 497-527. A confirmation of the results of this initial study has also been published: Voigt, Stefan, Jerg Gutmann and Lars Feld. "Economic Growth and Judicial Independence, a Dozen Years On: Cross-Country Evidence Using an Updated Set of Indicators." European Journal of Political Economy 38 (2015).

Voigt, Stefan. "The Economic Effect of Judicial Accountability: Cross-Country Evidence." European Journal of Law and Economics 25.2 (2008): pp. 95-123.

5 Shetreet, Shimon, and Jules Deschenes, eds. Judicial Independence: The Contemporary Debate. Dordrecht: Martinus Nijhoff, 1985 .

6 IвA, New Delhi Minimum Code of Judicial Independence, 1982. These standards have been reviewed a few times since the 1980s. The last set of standards has been adopted in 2008 and consolidated in 2015 under the name Mount Scopus International Standards of Judicial Independence. 
of specialized disputes, usually between the citizens and the administration".7 Zellick highlights the problematic nature of the term "administrative justice" which

implies that administrative justice is materially different from the ordinary civil justice administered by the courts; that it is really a part of the State's administrative arrangements rather than an integral part of its judicial system; and that administrative tribunals are fundamentally and conceptually distinct, and different, from those bodies labelled courts. ${ }^{8}$

The purpose of administrative justice is to provide a speedy and simple alternative to the "mainstream legal system with its notorious delays, complex procedures and expense." ${ }^{9}$ Zellick adds that a feature of administrative tribunals is that, "unlike courts, they can be multi-disciplinary and may include psychiatrists, economists, surveyors, valuers or other experts in addition to lawyers". 10 In this context, the notion of the independence of justice proposes new challenges to democracy because judicial independence is not easily applicable to administrative tribunals that form part of the executive and in which the executive may be the defendant.

In the following paragraphs I will highlight the growing importance attached to the notion of independence in international forums and the solutions offered to the conundrums posed by the application of judicial independence to the institutions which spring from the administrative state.

When Woodrow Wilson wrote in his essay on administration that, "it is getting harder to run a constitution than to frame one", he was probably not envisaging that one and a half century later the "the fourth branch" of the government was still growing. ${ }^{11}$ Indeed, the growth of the administrative state has

$7 \quad$ Zellick, Graham. "Administrative Justice and the Independence of the Judiciary." The Culture of Judicial Independence in a Globalised World. Eds. Shimon Shetreet and Wayne McCormack. Leiden: Brill Nijhoff, 2016, p. 68.

$8 \quad$ Zellick, op. cit., p. 68.

9 Zellick, op. cit., p. 69 .

10 Zellick, op. cit.

11 Wilson, Woodrow. "The Study of Administration." Political Science Quarterly 2.June (1887): pp. 197-222, p. 200. 
been intensely criticized by scholars. ${ }^{12}$ The administrative state can be defined simply as a constitutional order in which unelected bureaucrats, not elected representatives, are in charge of formulating policies, implementing them and adjudicating on them, sometimes using coercive powers. The term is used to describe both the growth of the government in general and the growth of the regulatory state.

Observing the phenomenon already in 1948, Waldo proposed in his seminal book on the administrative state that there was an intrinsic tension between democracy and bureaucracy that should invite public servants to protect democratic principles. Waldo argued that the dichotomy between politics and administration was false. However, he has championed the ideas that government should not be run like a business. Rather, he proposed that the public servants must impart to due process and access to government the efficiency found in scientific management. ${ }^{13}$

The notion of independence does not easily find its place in the conceptual framework presented above. However, recent works of political scientists, economists and lawyers stress independence as an important structural and procedural safeguard to be incorporated by government institutions.

The rise of the administrative power has been accompanied by the process of delegation of an increasing number of tasks in an increasing number of fields to Independent Regulatory Agencies (IRA s). Levi-Faur noted in 2005 that "such change is commonly captured in the notions of privatization and deregulation and understood as the outcome of the rise of neo-liberalism and the sweeping forces of economic globalization. Yet it has significant regulatory components that go largely unnoticed and that are incompatible with either neoliberalism or economic globalization". ${ }^{14} \mathrm{He}$ argues that the new order of regulatory capitalism, which has been in the making since the 1980s, differs from older forms of capitalist governance in its reliance on rules and rule enforcement. This in turn leads to (1) a new division of labour between state and society, (2) an increase in delegation that he defines as "remaking the boundaries between

12 Freedman, James. Crisis and Legitimacy: The Administrative Process and American Government. Cambridge: Cambridge University Press, 1978.

Lorch, Robert. Democratic Process and Administrative Law (Revised Edition). Detroit: Wayne State University Press, 1980.

Lowi, Theodore. The End of Liberalism: The Second Republic of the United States. 2nd edition. New York: W. W. Norton \& Company, 1979.

13 Waldo, Dwight. The Administrative State: A Study of the Political Theory of American Public Administration. New York: The Ronald Press Company, 1948.

14 Levi-Faur, David. "The Global Diffusion of Regulatory Capitalism." The ANNALS of the American Academy of Political and Social Science 598.March (2005), p. 12. 
the experts and the politicians", (3) proliferation of new technologies of regulation, (4) formalization of inter-institutional and intra-institutional relations and the proliferation of mechanisms of self-regulation in the shadow of the state, and (5) the growth in the influence of experts in general and of international networks of experts in particular. ${ }^{15}$ Vogel showed that these developments have changed the relationship between governments and corporations and have led to a stronger state, the true driver of this development. ${ }^{16}$

IRA s are the foundation of regulatory capitalism and three factors can describe their expansion: bottom-up, top-down, and horizontal. First, the establishment of IRAs was an attempt to improve credible commitment capacity when liberalizing and privatizing utilities and to alleviate the political uncertainty problem, namely, the risk to a government that its policies will be changed when it loses power. Second, in Europe, the process of Europeanization favoured the creation of independent regulators. Third, individual decisions were interdependent, as governments were influenced by the decisions of others in an emulation process where the symbolic properties of independent regulators mattered more than the functions they performed. ${ }^{17}$

Guidi noted that despite the increasing interest in IRAs, the existing research is unsatisfactory, either because it lacks any comparative perspective, or because it focuses only on the process of establishment of IRAs, leaving aside important questions concerning the amount of administrative discretion delegated to them. He observed that interest in the independence of IRAs is topical and the results of the studies conducted so far cannot be generalized. ${ }^{18}$ Guidi notes that especially in the field of regulatory authorities and competition policy, "scholars who study IRA s tend to analyse their institutional features without paying enough attention to the legislative and administrative framework in which agencies are embedded". ${ }^{19}$

15 Levi-Faur, op. cit., p. 27.

16 Vogel, Steven. Freer Markets, More Rules: Regulatory Reform in Advanced Industrial Countries. New York: Cornell University Press, 1996.

17 Levi-Faur, David and J. Jacint. "Preface: The Making of a New Regulatory Order." The ANNALS of the American Academy of Political and Social Science 598.March (2005): pp. 6-9.

Gilardi, F. "The Institutional Foundations of Regulatory Capitalism: The Diffusion of Independent Regulatory Agencies in Western Europe." The ANNALS of the American Academy of Political and Social Science 598.March (2005), p. 84.

18 Guidi, Mattia. "Delegation and Varieties of Capitalism: Explaining the Independence of National Competition Agencies in the European Union." Comparative European Politics 12.3 (2014): pp. 343-365.

Guidi (2014), op. cit. 
Scholars of political science assume that politicians have very little incentive to delegate powers to independent authorities, such as in the field of competition law. They use the principle-agent theory to propose that the legislator - the principal - and the competition authority - the agent - pursue different goals and would prefer to remain separated. ${ }^{20}$ Other scholars propose that delegation can help politicians to diminish their workload, to understand and regulate highly complex technical issues. ${ }^{21}$ Also, delegation allows shifting the responsibility for the decisions adopted. ${ }^{22}$

Similarly, some authors argue that, as a general rule, the government should not delegate wide policy discretion to the agent because the exercise of discretion is difficult to control. ${ }^{23}$ Other authors propose the contrary argument; for them the wide discretion of the agent justifies closer control by the government. ${ }^{24}$

In addition, Gilardi argues that delegation to independent authorities can be a means for politicians to increase the credibility of their policy commitments. In line with this view, regulators have been found to be formally more independent in utilities than in other economic regulation, and in economic regulation more than in social regulation. On the other hand, the political uncertainty argument states that delegation can be employed by a government fearing replacement to prevent policies from being changed by the next government. The analysis has shown that, consistent with this reasoning, the formal independence of regulators first increases as replacement risk increases, but then decreases when frequent changes in the partisan composition of governments implies that a party or coalition is likely to gain office at regular intervals. Finally, it has been shown that the institutional context matters: regulators tend to be less independent in countries with many veto players. ${ }^{25}$

$20 \quad$ Miller, G.J. "The Political Evolution of Principal-Agent Models." Annual Review of Political Science 8.1 (2005): pp. 203-250.

Ross, S. A. "The Economic Theory of Agency: The Principal's Problem." The American Economic Review 63.2 (1973): pp. 134-139.

21 Franchino, Fabio. "Efficiency or credibility? Testing the Two Logics of Delegation to the European Commission." Journal of European Public Policy 9.5 (2002): pp. 677-694.

22 Fiorina, M. P. "Legislative Choice of Regulatory Forms: Legal Process or Administrative Process?" Public Choice 39.1 (1982): pp. 33-66.

23 Ottow, A., and S. Lavrijssen. "The Legality of Independent Regulatory Authorities." The Eclipse of the Legality Principle in the European Union. Eds. Leonard Besselink, Frans Pennings and Sacha Prechal. Wolter Kluwer, 2011, pp. 73-95.

24 Kovacic, W.E. "Competition Agencies, Independence, and the Political Process." Competition Policy and the Economic Approach. Eds. J. Drexl, W. Kerber and R. Podszun. Cheltenham: Edward Elgar, 2011, p. 292.

25 Gilardi, F. "The Formal Independence of Regulators: A Comparison of 17 Countries and 7 Sectors." Swiss Political Science Review 11.4 (2005), p. 157. 
Lastly, Gilardi proposed five dimensions to assess the formal independence of regulators: the status of the agency head (for example, term of office, appointment and dismissal procedure), status of the members of the management board, relationship with government and parliament, financial and organizational autonomy and regulatory competencies. ${ }^{26}$ All these can act as safeguards towards a regulator's independence.

Independence is usually regarded as a positive characteristic for regulatory agencies and competition authorities. ${ }^{27}$ First of all, the functions of these bodies are para-judicial and this places an expectation on them that they make decisions solely on the basis of law and that they judge facts impartially. Second, an independent competition authority is attractive for private investment and creates a healthy business environment that is insulated from political fluctuations. Third, in many countries, national governments still own important market players and it is crucial for the national and international competitors operating in those markets to have an executive which handles competition issues impartially. ${ }^{28}$

An important question concerning the justification for a competition authority's independence is its impact on the authority's performance and welfare effects. ${ }^{29,30}$

A few respected authors contest the relevance of the notion of independence to the work performed by competition authorities. Thus, Monti argues that, rather than speaking of independence from government or from business or consumer interests, the public debate would be better off speaking of an authority's appropriate degree of dependence. ${ }^{31}$ Monti suggests that a more convincing justification for the independence of competition authorities is linked with the commitment that the state has made towards a particular economic order. ${ }^{32}$

26 Gilardi, op. cit., p. 146.

27 Jenny, F. "Competition Authorities: Independence and Advocacy." The Global Limits of Competition Law. Eds. I. Lianos and D.D. Sokol. Stanford: Stanford University Press, 2012, p.166.

Mateus, A. "Why Should National Competition Authorities Be Independent and How Should they Be Accountable?" European Competition Journal 3.1 (2007).

28 Guidi (2014), op. cit.

29 Guidi, Mattia. "The Impact of Independence on Regulatory Outcomes: the Case of EU Competition Policy." Journal of Common Market Studies April (2015).

30 Bergman, Mats. "Quis Custodiet Ipsos Custodes? Or Measuring and Evaluating the Effectiveness of Competition Enforcement." De Economist 156.4 (2008): pp. 387-409.

31 Monti, Giorgio. Independence, Interdependence and Legitimacy: The EU Commission, National Competition Authorities, and the European Competition Network. EU I Working Paper Law No. 2014/o1, European University Institute. 
In 2008, the United Nations Secretariat on Trade and Development (UNCTAD) published a note highlighting that most countries recognized that it was desirable to prevent the implementation of narrow interest group goals when enforcing competition law. To this end, countries have put in place various checks and balances to ensure the independence and accountability of competition authorities. ${ }^{33}$

The note acknowledged that there was widespread agreement that "independent regulators were at the core of regulatory governance in liberalized economies and a globalized world economy". 34

Also, the note stressed that the UNCTAD Model Law on Competition was formulated on the assumption that the most efficient type of administrative authority for competition enforcement "is likely to be one that (a) is quasiautonomous or independent of the Government, with strong judicial and administrative powers for conducting investigations and applying sanctions; and (b) provides the possibility of recourse to a higher judicial body". ${ }^{35}$ In a more recent document, the UNCTAD proposed that independence of competition authorities was "variable and it is often more useful to speak in terms of degrees of independence rather than absolute independence" because "no competition authority can be completely independent from the Government structure of which it is an integral part". ${ }^{36}$

The UNCTAD acknowledged that the structure of a competition enforcement system has an important bearing on the authority's independence or perceived independence. The following elements are listed to influence the independence of the competition authorities: (1) separation of the investigatory arm from the adjudicating decision-making body; (2) physical location away from the supervising ministry building; (3) budget independence; (4) appointment procedure of officials of the competition authority and (5) qualifications of members of the competition authority. ${ }^{37}$

33 UnCTAD. Independence and Accountability of Competition Authorities. Document TD/B/COM.2/CLP/67 of 14 May 20o8. Available at https://unctad.org/meetings/en/ SessionalDocuments/CCPB_IGE2014_UNCTADNOTE_EMCF_en.pdf accessed on 23 February 2021.

34 UNCTAD (2008), quoted above, p. 3.

35 UnCTAD. The Model Law on Competition. Available at https://unctad.org/en/Pages/DITC/ CompetitionLaw/The-Model-Law-on-Competition.aspx accessed on 23 February 2021.

36 unctad. Good Governance Guidelines: Independence and Transparency. Document UNCTAD/DITC/CLP/20016/2 of 22 June 2016, p. 1. Available at https://unctad.org/en/ PublicationsLibrary/ditcclp2o16d2_en.pdf accessed on 23 February 2021. 


\subsection{OECD Roundtable on Changes in Institutional Design of Competition Authorities}

In December 2014, the Organisation for Economic Co-operation and Development (OECD) organized a roundtable meeting on recent changes in institutional design which focused on three major topics: (1) the combination of different functions in a single authority; (2) the notion of independence; and (3) the internal governance of the authority. ${ }^{38}$

In relation to the topic of multi-function authorities, Fels highlighted a recent trend of integrating competition enforcement, consumer protection and regulatory powers within the same authority. ${ }^{39} \mathrm{He}$ observed that "there is kind of a 'North Sea dumping' effect in the world of competition law, which means that governments often resolve a given problem by delegating it to the competition authority".40

In relation to the question of independence of competition authorities, Professor Kovacic presented a paper in which he pointed out that the insulation of competition authorities from political process is a highly desirable characteristic and a sign of institutional maturity. However, complete isolation from politics is both unattainable and undesirable. ${ }^{41}$

The representative of the OECD's Directorate for Public Governance and Territorial Development noted that, due to the rather "tricky" nature of the problem, the OECD could not come up with a set of normative criteria for independence. He stressed, however, that a survey carried out in 2013 indicated that a majority of the regulators receive strategic direction for their long-term strategy, but "most of them operate with a high degree of independence on individual cases and appeals".42

The Business and Industry Advisory Committee of the OECD (BIAC) argued in their submission that the institutional design of competition authorities is

38 OECD. Summary Record of the Roundtable on Changes in Institutional Design. DAF/COMP/ $\mathrm{M}(2014) 3 / \mathrm{ANN}$ /FINAL. Available at http://www.oecd.org/officialdocuments/publicdisplaydocumentpdf/?cote=DAF $/ \mathrm{COMP} / \mathrm{M}(2014) 3 / \mathrm{ANN} 4 /$ FINAL\&doclanguage $=$ en accessed on 23 February 2021.

Fels, A. and H. Ergas (2014). Institutional Design of Competition Authorities. DAF/COMP/ WD(2014) 85 Paper drafted as a Background Note for the Competition Commission's session on Changes in Institutional Design. Available at: http://www.oecd.org/officialdocuments/publicdisplaydocumentpdf/?cote $=\mathrm{DAF} / \mathrm{COMP} / \mathrm{WD}(2014) 85 \&$ doclanguage $=$ en accessed on 23 February 2021.

40 OECD (2014), quoted above, p.3.

41 Kovacic, op. cit.

42 OECD (2014), quoted above, p. 19. 
critically important for the jurisdiction's effectiveness and should ensure the most pro-competitive outcomes possible. The BIAC stressed, however, that "it must do so in a manner that will maintain the confidence of businesses and citizens alike, without which the enforcement of competition laws will ultimately lack political, legal and economical legitimacy. A successful design must also reflect the increasing reality that government agencies operate with strict budgetary constraints". 43

The BIAC showed that there is evidence to suggest that greater independence from the government was the factor most frequently identified as likely to lead to better promotion of competition law. ${ }^{44}$

Turning to the issue of the separation of the investigative and adjudicative functions of the competition authorities, the BIAC noted that

housing both investigative and adjudicative functions 'under one roof' can lead to significant cost benefits. However, as with the lack of independence from government, the lack of separation between the investigative and adjudicative functions can raise significant concerns over the perception of fairness or bias, rising to the level of legal concern in certain jurisdictions. ${ }^{45}$

\subsection{International Competition Network}

The 2019 Conference of the International Competition Network (ICN) has been dedicated between others to practices for the investigative process during competition law proceedings. The published recommendations acknowledge that fair and effective agency investigative process is essential to sound competition law enforcement and that the credibility of competition agency is closely linked to both the agency's integrity of investigative process and the public's understanding of such process. At the same time, ICN highlighted that fairness can be achieved using different approaches. ICN proposed that fairness of

43 oecD. Roundtable on Changes in Institutional Design of Competition Authorities, Note by BIAC. DAF/COMP/WD(2014)126, p. 2. Available at http://www.oecd.org/officialdocuments/publicdisplaydocumentpdf/?cote=DAF/COMP/WD $(2014) 126 \&$ doclanguage $=$ en accessed on 23 February 2021.

44 OECD. Global Forum on Competition: The Objectives of Competition Law and Policy. CCNM/ GF/COMP(2003)3. Available at http://www.oecd.org/daf/competition/2486329.pdf accessed on 23 February 2021.

OECD (2003), quoted above, p. 10. 
investigative process includes "availability and use of effective agency investigative tools, transparency and engagement with those subject to an investigation (investigated parties and third parties), internal checks and balances on enforcement process, and protection of confidential information". ${ }^{46}$

ICN proposed twelve recommendations for effective and fair investigative process:

(1) Competition authorities should have appropriate resources and investigative tools to enforce competition law;

(2) Investigative tools for competition law investigations should be based on an appropriate legal framework setting out criteria and procedural requirements for their use;

(3) Competition agencies' internal procedures should address the use of their investigative tools and the information gathered during an investigation. For example, before issuing a request for information, competition agencies should weigh the circumstances of the case against the principles of proportionality, relevance and burden;

(4) Competition law and policies that govern competition law enforcement should be transparent, reinforcing the values of accountability, predictability and fairness;

(5) Transparency to parties during a competition law investigation is a basic attribute to effective competition law enforcement. At the same time, the extent of the investigative transparency is subject to the agency's discretion and should not limit its discretion to pursue new or additional theories;

(6) Engagement between the agency and the parties under investigation on important factual, legal, economic and procedural matters is a basic attribute of sound and effective competition enforcement;

(7) Engagement with third parties also promotes more informed enforcement;

(8) Internal agency safeguards - such as internal procedures and practices to ensure consistent and impartial investigative processes - are a basic attribute of sound and effective competition enforcement;

(9) Investigative recommendations and findings should be thoroughly evaluated before being implemented. Personal bias, political interference, national protectionism or interests of the industry should not play a role in the enforcement process;

46 ICN. ICN Recommended Practices for Investigative Process. Available at: https://www. internationalcompetitionnetwork.org/wp-content/uploads/2019/o5/RPs-InvestigativeProcess.pdf accessed on 23 February 2021. 
(10) Confidential information should be protected during competition enforcement;

(11) Competition agencies should have clear policies concerning the disclosure of information;

(12) Applicable legal privileges should be respected. ${ }^{47}$

\subsection{Independence of European Regulators}

Whereas the discussions concerning the independence of NCAs and the European Commission are relatively new, European law contains a plethora of legislative provisions and case-law concerning the independence of National Regulatory Authorities (NRA s).

In the field of telecommunications, member states have to guarantee the independence of NRA s by ensuring that they are legally distinct from and functionally independent of all organisations providing electronic communications networks, equipment or services. ${ }^{48}$ Where member states retain ownership or control of undertakings, they have to ensure effective structural separation of the regulatory function from activities associated with ownership or control. Member states must also ensure that NRA s exercise their powers impartially and transparently. ${ }^{49}$

In addition to ensuring that the NRA s are independent, member states must ensure the right to appeal for any user or undertaking affected by a decision of the NRA. The appeal body must be independent of the parties involved, and must have the appropriate expertise available to carry out its functions and to ensure that the merits of each case are duly taken into account. ${ }^{50}$

In the field of energy, the preamble to Directive 2009/72 acknowledged that the effectiveness of regulation is frequently hampered by the lack of independence of regulators from government, as well as insufficient powers and discretion..$^{51}$ Energy regulators need to be fully independent from any public or

47 ICN, quoted above, pp. 2-10.

48 See Directive 2002/21/EC of the European Parliament and of the Council of 7 March 2002 on a common regulatory framework for electronic communications networks and services, OJ L 108, 24.4.2002, p. 33 as amended by Directive 2009/140/EC of the European and of the Council of 25 November 2009, OJ L 337, 18.12.2009, p. 37 .

49 Directive 2002/21/EC, quoted above, Article 3.

50 Directive 2002/21/EC, quoted above, Article 4.

51 Directive 2009/72/EC of the European Parliament and of the Council of 13 July 2009 concerning common rules for the internal market in electricity and repealing Directive 2003/ 54/EC, OJ L 211, 14.8.2009, p.55. 
private interests and the independence requirement is fully compatible both with judicial review and parliamentary supervision in accordance with the constitutional laws of the member states. ${ }^{52}$ To address this issue, the directive imposes minimum independence criteria for the transmission system owner, the transmission system operator, for their staff and management and, lastly, for the NRA. The NRA in particular must have independent decision-making powers, staff and budget to allow it to act impartially and transparently. ${ }^{53}$

In the field of railways, Directive 2012/34/EU imposes independence requirements on railway undertakings, on the essential functions of infrastructure manager, and on NRA s. ${ }^{54}$ According to the directive, the NRA

shall be a stand-alone authority which is, in organisational, functional, hierarchical and decision-making terms, legally distinct and independent from any other public or private entity. It shall also be independent in its organisation, funding decisions, legal structure and decisionmaking from any infrastructure manager, charging body, allocation body or applicant. It shall furthermore be functionally independent from any competent authority involved in the award of a public service contract. ${ }^{55}$

The directive requires member states to provide clear and transparent rules for the appointment of board members of NRA s, appointment which has to be based on merit, competence and relevant experience. In particular,

Member States shall ensure that these persons act independently from any market interest related to the railway sector, and shall therefore not have any interest or business relationship with any of the regulated undertakings or entities. To this effect, these persons shall make annually a declaration of commitment and a declaration of interests, indicating any direct or indirect interests that may be considered prejudicial to their independence and which might influence their performance of any function. These persons shall withdraw from decision-making in cases which concern an undertaking with which they had a direct or indirect connection during the year before the launch of a procedure. ${ }^{56}$

52 Directive 2009/72/EC, quoted above, Article 33-34.

53 Directive 2009/72/EC, quoted above, Article 35.

54 Directive 2012/34/EU of the European Parliament and of the Council of 21 November 2012 establishing a single European railway area, oJ L 343, 14.12.2012, p. 32.

55 Directive 2012/34/EU, quoted above, Article 55.

56 Directive 2012/34/EU, quoted above. 
Lastly, in the field of data protection, EU law acknowledges that "complete independence" of the supervisory authorities is an essential component of the protection of individuals in instances when their personal data is processed. ${ }^{57}$ EU law requires that all institutions dedicated to the protection of data set up in the member states - the personal data protection official, the supervisory authority and the Working Party on the Protection of Individuals - must be independent and act independently. 58

\subsection{The European Competition Network}

The economic crisis that started in 2008 and the budgetary cuts performed in some member states of the EU had a surprising consequence - the initiation of discussions concerning the independence of the national competition authorities. In 2010, the Meeting of Heads of the European competition authorities published a resolution showing the central role played by effective competition enforcement in the functioning of market economies. ${ }^{59}$ The resolution also stressed that NCA s are "trusted advisors to governments and legislators, advocating pro-competitive approaches and promoting a culture of competition in their jurisdictions". ${ }^{60}$ However, in order to fulfil the roles assigned to them, NCA s need appropriate infrastructure and expert resources to intervene and handle complex matters of law and economics. ${ }^{61}$

The Commission included the concerns raised by the Meeting of Heads of the European competition authorities in its communication Ten Years of Antitrust Enforcement under Regulation 1/2003 and its accompanying documents. ${ }^{62}$ The Commission noted that in the vast majority of member states, the NCA s benefit from a certain degree of independence but the extent of their

57 Directive 95/46/EC of the European Parliament and of the Council of 24 October 1995 on the protection of individuals with regard to the processing of personal data and on the free movement of such data, OJ L 281, 23.11.1995, p. 31.

58 Directive 95/46/EC, quoted above, Article 18(2) and Article 28 respectively.

59 European Competition Network. Resolution of the Meeting of Heads of European Competition Authorities of 16 November 2010 on Competition Authorities in the European Union - the Continued Need for Effective Institutions. Available at http://ec.europa.eu/competition/ecn/ncas.pdf accessed on 23 February 2021.

6o European Competition Network, quoted above, p. 1.

61 European Competition Network, quoted above, p. 2.

62 European Commission. Commission Staff Working Document. Enhancing competition enforcement by the Member States' competition authorities: institutional and procedural issues. SWD(2014) 231/2. Available at http://ec.europa.eu/competition/antitrust/legislation/swd_2014_231_en.pdf accessed on 23 February 2021. 
independence and the degree of supervision exercised by other state bodies varies. The Commission also pointed out that some NCAs may be subject to general supervision or to general instructions by executive or the legislative powers. More importantly, the degree of supervision

may range from guiding and coordinating the NCA's activities or outlining the NCA's activities without intervening or deciding on individual cases or on the actual application of the law, to giving instructions regarding the general application of the law or regarding budgetary issues or general policy matters which is also directed to other governmental institutions. In a number of Member States, the minister may instruct the NCA, for example, to carry out sector inquiries or competition studies or analyses, which the NCA cannot otherwise initiate itself, but without, however, directing the outcome. ${ }^{63}$

The Commission also addressed the issue of multi-function authorities, showing that while a minority of NCA s are exclusively responsible for competition enforcement, the majority of NCA s now have additional responsibilities in various areas such as consumer protection, public procurement and the supervision of liberalised sectors (energy, post, telecommunications and railways). ${ }^{64}$

The communication emphasized the Commission's achievements in the field of competition law and proposed a few fields for further consideration, the first being the institutional position of the NCAs. Despite the progress made by some member states in the field of independence and impartiality of NCA s, the achievements are "fragile and can be rolled back at any time".65 A few elements can ensure that progress continues to be pursued in this field: - minimum standards to ensure the independence of the NCAs, but also of their management or board members;

- sufficient financial and human resources;

- budgetary autonomy;

63 European Commission. Commission Staff Working Document. Enhancing competition enforcement by the Member States' competition authorities: institutional and procedural issues, quoted above, p. 6.

64 European Commission. Commission Staff Working Document. Enhancing competition enforcement by the Member States' competition authorities: institutional and procedural issues, quoted above, p. 9 .

65 European Commission. Commission Staff Working Document. Enhancing competition enforcement by the Member States' competition authorities: institutional and procedural issues, quoted above, p. 9 . 
- clear and transparent appointment procedures for the NCA s management or board members;

- objective dismissals;

- rules concerning conflicts of interests and incompatibilities of NCA s management board. ${ }^{66}$

Furthermore, in December 2014, the EU Director-General for Competition, Alexander Italianer, addressed the issue of the independence of National Competition Authorities in a speech delivered at a competition conference in Vienna. He highlighted the importance of the NCA s being "independent, properly funded and adequately staffed".67

Italianer noted that there are currently two models of institutional design in Europe: the administrative model, which is based on the cumulation - within the same institution - of enforcement and judicial control functions; and the judicial model, which has an administrative authority entrusted with the investigation of cases and a court entrusted with taking a decisions on substance, sanctions or both. A large majority of members of the EU have an administrative model. Italianer noted however that "independence is a key requirement regardless of institutional design".68

Second, Italianer stressed that the independence and impartiality of the NCA s are closely linked and affect their legitimacy, credibility and efficacy. ${ }^{69}$ Practices such as the direct government influence over appointments, staff rotation of NCAs following elections, misuse of NCA budgets by government to gain leverage or as retaliation measures, and intrusive investigations into NCA s' decision-making by governments go against the principle of independence. ${ }^{70}$

66 European Commission. Commission Staff Working Document. Enhancing competition enforcement by the Member States' competition authorities: institutional and procedural issues, quoted above, p. 9 .

67 European Commission. Commission Staff Working Document. Enhancing competition enforcement by the Member States' competition authorities: institutional and procedural issues, quoted above, p. 2.

68 European Commission. Commission Staff Working Document. Enhancing competition enforcement by the Member States' competition authorities: institutional and procedural issues, quoted above, p. 2.

69 European Commission. Commission Staff Working Document. Enhancing competition enforcement by the Member States' competition authorities: institutional and procedural issues, quoted above, p. 4.

70 European Commission. Commission Staff Working Document. Enhancing competition enforcement by the Member States' competition authorities: institutional and procedural issues, quoted above, p. 5 . 
Third, Italianer stressed that the independence of NCA s in the EU should be built on three elements: independently appointed staff, unfettered discretion to choose which cases to investigate and control over budgets. ${ }^{71}$

He concluded that "being able to function without the threat of interference from political authorities and vested interests is a cornerstone of the rule of law".72

\subsection{Empowering NCA s - Directive 1/2019}

At the beginning of 2019, the EU adopted a directive meant to empower the NCA s to be more effective enforcers of competition law in light of the direct applicability of Articles 101 and 102 T FEU. ${ }^{73}$

This document is relevant to the topic of this book for a few reasons. On the one hand, the first provision of the directive is dedicated to the need to respect fundamental rights by the NCA s and the member states while they are enforcing Articles 101 and $102 \mathrm{TFEU}^{.74}$ The second provision of the directive is dedicated to the need to guarantee the NCA s independence when enforcing Articles 101 and $102 \mathrm{TFEU} .{ }^{75}$ This textual prioritization of fundamental rights and independence during EU competition law enforcement is in line with new constitutional design of the EU that has fundamental rights as one of its priorities.

On the other hand, Directive 1/2019 imposes independence and impartiality standards that are very close to the standards formulated by the ECtHR in this field. For example, the directive stipulates that member states must ensure

71 European Commission. Commission Staff Working Document. Enhancing competition enforcement by the Member States' competition authorities: institutional and procedural issues, quoted above, p. 6 .

72 European Commission. Commission Staff Working Document. Enhancing competition enforcement by the Member States' competition authorities: institutional and procedural issues, quoted above, p. 3 .

73 Directive (EU) 2019/1 of the European Parliament and of the Council of 11 December 2018 to empower the competition authorities of the Member States to be more effective enforcers and to ensure the proper functioning of the internal market, quoted above.

74 Directive (EU) 2019/1 of the European Parliament and of the Council of 11 December 2018 to empower the competition authorities of the Member States to be more effective enforcers and to ensure the proper functioning of the internal market, quoted above, article 3 .

75 Directive (EU) 2019/1 of the European Parliament and of the Council of 11 December 2018 to empower the competition authorities of the Member States to be more effective enforcers and to ensure the proper functioning of the internal market, quoted above, article 4 . 
structural, operational and budgetary standards of independence and impartiality for the NCA s. ${ }^{76}$

\subsection{The Difficult Case for the Independence of the European Commission}

It was common practice in the 1990 and the 2000 s for all the US presidents to personally intervene in EU competition proceedings in favour of anti-trust clearances of US firms. ${ }^{77} \mathrm{~A}$ well-known case is the General Electric/Honeywell merger during which the Commissioner for Competition Mario Monti has complained about the alleged interference of the US president George Bush in the following terms: "I deplore attempts to misinform the public and to trigger political intervention".78

In addition, the press recounts multiple instances of political pressure exerted on national competition authorities in the European Union. ${ }^{79}$ At the same time, the appointment of each new Commissioner for Competition is accompanied by a debate concerning the proposed candidate's involvement with business. In this respect, Neelie Kroes - who was nominated Commissioner for Competition in 2004 - had been an active politician in the Netherlands and served as minister of transport, public works and water management in the 1980s. She then took a number of corporate jobs and sat on the boards of Royal P\&O Nedlloyd, New Skies Satellites, Thales Netherlands, MMo2, and Volvo amongst others. Neelies Kroes listed 25 corporate jobs in her nomination $\mathrm{CV}$. The press noted that "EU officials acknowledge that they have never dealt with a commission candidate with such extensive business ties - and potential conflicts" and that, in addition, Neelies Kroes

76 Directive (EU) 2019/1 of the European Parliament and of the Council of 11 December 2018 to empower the competition authorities of the Member States to be more effective enforcers and to ensure the proper functioning of the internal market, quoted above, article 4.

77 Karagiannis, op. cit., p. 686.

78 "Monti Slams US Critics." BBC. 18 Jun 2001. Available at http://news.bbc.co.uk/2/hi/business/1395739.stm accessed on 23 February 2021. Reporting President G. W. Bush's intervention in favour of allowing the $\mathrm{GE} /$ Honeywell merger.

79 Brown, K. "Keeping Watchdogs on a Short Leash: The Government's Approach to Competition Has Increased Suspicions That It Will Not Tolerate Truly Independent Regulators." Financial Times. 10 Mar 2000, p. 23.

Hanretty, Chris and Christel Koop. "Shall the Law Set Them Free? The Formal and Actual Independence of Regulatory Agencies." Regulation \& Governance 7.2 (2013): pp. $195^{-214}$. 
has not actually disclosed all of her former employers, including the arms manufacturer Lockheed Martin. ${ }^{8081}$ Lastly, at the end of her assignment as Commissioner for Competition, Neelies Kroes accepted two positions that raised further questions concerning conflict of interests: special government envoy for start-up companies in the Netherlands and special adviser to the Bank of America Merrill Lynch. ${ }^{82}$

Other commissioners have also been criticized for their involvement with various businesses. ${ }^{83}$ Taking into account that the College of Commissioners adopts all decisions concerning competition on the European market, it becomes increasingly important to reflect on the impact of a commissioner's background on the adopted decisions.

Political scientists have long been concerned with hybrid executive power whose civil servants are concomitantly expected to act as impartial technocrats and as partial participants in the political process. Several institutional characteristics exacerbate this tension within the European Commission:

In conjunction with the College of Commissioners, the officials of the European Commission have a constitutional obligation to set the legislative agenda because they have exclusive formal competence to draft $\mathrm{EU}$ legislation. (...) They promote the policies of their directorate to private interests, politicians, public, and, last but not least, reluctant Commission colleagues. They direct negotiations between the Commission, on the one hand, and the Council of Ministers' working groups, the European Parliament, and interest groups, on the other. They broker legislative negotiations between the Council of Ministers and the Executive Parliament. Yet, as career civil servants, they also execute and administer political decisions taken by elected leaders. ${ }^{84}$

8o Barrionuevo, A. and D. Michaels. "EU Antitrust Nominee Did Not Disclose All Ties." Wall Street Journal. 21 Oct 2004.

81 Corporate Europe Observatory. Neelies Kroes. Revolving Door Report, 1 Mar 2015. Available at http://corporateeurope.org/revolvingdoorwatch/cases/neelie-kroes accessed on 23 February 2021.

82 Corporate Europe Observatory. Neelies Kroes, quoted above.

83 See for example, Flues, Fabien. "The many business dealings of Commissioner-designate Miguel Arias Canete." Corporate Europe Observatory. 23 Sep 2014. Available at http:// corporateeurope.org/power-lobbies/2014/og/many-business-dealings-commissionerdesignate-miguel-arias-canete accessed on 23 February 2021.

84 Hooghe, Liesbet. The European Commission and the Integration of Europe: Images of Governance. Cambridge: Cambridge University Press, 2001, p. 6. 
However, despite growing general concerns about untamed administrative power and specific concerns about individuals nominated as commissioners, the case for the independence of the Commission is rather difficult to make.

The first difficulty stems from the fact that the issue of independence of the Commission is inevitably placed at the crossroads of notions that are themselves charged with multiple meanings. The separation of powers, the growing importance of executive power, the changing nature of modern bureaucracy, the delegation of powers, and the discretion and autonomy of the executive are concepts that carry all the contradictions of modern democracies and that inevitably affect attempts to define the notion of independence.

The second difficulty arises from the continuous tension between developments in the field of independence at the national and international levels. The development of national competition authorities, independent regulatory authorities and other national regulatory authorities has partially focused on independence as a core element of institution-building. The European Commission has been a champion and a supporter of this transition. However, this exercise of transformation has been accompanied only partially by an exercise in self-reflection on the same subject. To what extent achievements in legal thinking at the national level are to be reflected at the supranational level is an old debate that does not spare the issue of the independence of the Commission.

Lastly, the waves of critique directed at the European Commission and its resulting transformations have inadvertently been rooted in the idea that independence can strengthen the Commission's autonomy, thus sheltering it from its political masters' whims. However, this view favours a politicized view of independence as a tool in the counter-offensive against the hunt for runaway bureaucracies. Also, this view distances itself from the notion of independence as a binding legal requirement across the democratic world, a burden and a responsibility that ensures fair play during a legal process, but also a constant, unaffected modus operandi.

Those who oppose the case for a more independent EU Commission offer structural and procedural reasons. Thus, Karol von Miert has famously proclaimed that competition policy was not neutral, it was in fact "politics".85 Focusing on enforcement procedures, Monti argues that, although the decisions in individual competition law cases are voted on by the College of Commissioners, the bulk of the work is carried out by the DG COMP. ${ }^{86}$ On

85 Wilks, S., and L. McGowan. "Competition Policy in the European Union: Creating a Federal Agency?" Comparative Competition Policy: National Institutions in a Global Market. Eds. G.B. Doern and S. Wilks. Oxford: Clarendon Press, 1996, pp. 225-267. 
the one hand, important decisions concerning procedural issues that precede the adoption of a final decision, such as decisions to initiate proceedings, to reject complaints or to issue statement of objections, are vested with the Commissioner for Competition or delegated to the Director General. ${ }^{87}$ On the other hand, Monti notes that "in the vast majority of cases the College defers to the DG COMP's proposed course of action. This is evidenced by the fact that most competition decisions are agreed with written procedure, which reduces the scope for discussing the wider policy ramifications of a proposed decision".88

Monti concludes that the work of DG COMP is relatively well-insulated from the influence of politics and private interests both during the procedures by which the cases are screened for being placed on the agenda and during the investigation and adjudication stages. He accepts however that there is a risk of lobbying from parties seeking favourable treatment. ${ }^{89}$

More recently, Karagiannis has argued that "collegiality corresponded to an ingenious institutional solution to the problem of committing to a farreaching, exclusive, open-ended, and, therefore, highly risky agreement" and that "the institution of collegiality in the EC is not aimed at securing commitment to specific policy options, but commitment to a negotiated implementation of the Treaty". 90

87 The legal basis for this is Commission Decision of 24 February 2010 amending its Rules of Procedure 2010/138/EU, Euratom, oJ L 55, 5.3.2010, p. 6o, Article 13. See also the European Commission. Antitrust: Manual of Procedures: Internal DG Competition Working Documents on Procedures for the Application of Articles 101 and 102 TFEU. March 2012, Sections 2.2 and 2.3. Available at http://ec.europa.eu/competition/antitrust/antitrust_ manproc_3_2012_en.pdf accessed on 23 February 2021.

88 Monti, op. cit., p. 9.

89 Monti, op. cit., p. 9-10.

$90 \quad$ Karagiannis, op. cit., p. 703 . 